\title{
TRANSFORMASI KEPEMIMPINAN BIROKRASI
}

\author{
Oleh: Awang Anwaruddin ${ }^{1}$
}

\begin{abstract}
Since the last five decades, the behaviourist have scientifically analyzed the implementation of leadership within organizations, and found that leadership is a complicated process that can be described in various theories and models. However, there are a lot of contradictive and over-lapped hypotheses and types of leadership.

Hence, it's difficult to define the ideal leadership. The difficulty is due to the misunderstanding of leadership concept, started from the idea that leadership is something that you own or gain-the same as a certain position in the structure of organization. However, if you have the desire and willpower, no matter who you are and where you work, you can become an effective leader through a never ending process of self-study, education, training, and experience. To inspire your workers into higher levels of teamwork, for example, there are certain things you must learn, understand, and do. These do not come naturally, but are acquired through continual work and study. Good leaders are continually working and studying to improve their leadership skills; they are not resting on their laurels.
\end{abstract}

Keywords: transformasi kepemimpinan, birokrasi.

\section{Pendahuluan}

Akhir-akhir ini isu reformasi birokrasi mulai mencuat kembali ke permukaan, terutama setelah berbagai permasalahan strategis timbul akibat kelemahan sistem organisasi pemerintahan ini. Diawali oleh krisis multi-dimensi yang berlarut-larut akibat arus globalisasi yang tak terbendung, kemudian berlanjut dengan krisis ekonomi, isu korupsi, lemahnya pelayanan publik, dan berbagai permasalahan yang mengganggu keharmonisan kehidupan berbangsa dan bernegara. Sebagai 'an organization with a certain position and role in running the government administration of a country' (Mustopadidjaja, 2002), wajar apabila birokrasi dianggap paling bertanggung-jawab atas timbulnya permasalahan sosial tersebut.

Namun, kita tahu, sampai sekarang pemerintah belum merumuskan suatu grand strategy terhadap reformasi birokrasi. Undang-Undang Pelayanan Publik memang akan segera diterbitkan (Effendi, 2005), akan tetapi masih saja belum ada kejalasan tentang grand scenario yang akan dimainkan pemerintah dalam melakukan reformasi birokrasi. Tidak heran kalau berbagai ahli dan praktisi menggagas berbagai konsep pembaharuan birokrasi.

Drs. Awang Anwaruddin, M.Ed. adalah Pembantu Ketua I STIA LAN Bandung, lulusan Exeter University, the United Kingdom, Doctor Candidate dalam Ilmu Administrasi Universitas Padjadjaran, Bandung, serta konsultan manajemen dan Trainer berbagai program pengembangan SDM dan Bimtek manajemen pemerintahan. 
Misalnya Soebhan (2005) mengemukakan bahwa prioritas pertama yang perlu dilakukan adalah mengenalkan konsep kewirausahaan di lingkungan birokrasi guna mendongkrak kebangkitan ekonomi. Pendapat ini selaras dengan Deklarasi Seoul yang dicetuskan para praktisi dan ahli pemerintahan dunia dalam Global Forum VI pada 27 Mei 2005 lalu, yang merekomendasikan perlunya implementasi reinventing government yang berorientasi pada transparansi, partispatori, inovasi, akuntabilitas, dan making small head quarter and bigger branches (Thoha, 2005).

Sementara itu, Gintings (2005) sepakat dengan langkah pemerintah untuk mengawali reformasi birokrasi melalui perbaikan pelayanan publik. Sebagaimana yang dilakukan di berbagai negara yang mengalami perubahan dari sistem otoritarian ke sistem politik demokrasi, perbaikan pelayanan publik akan secara lebih langsung dirasakan oleh masyarakat sebagai perbedaan yang signifikan dari sistem sebelumnya

Dalam kesempatan yang sama, Zuhro (2005) berpendapat bahwa reformasi birokrasi harus dilakukan dengan memperbaiki seluruh sistemnya agar kinerja lembaga pemerintahan dapat segera ditingkatkan. Tiga hal yang perlu dilakukan adalah (1) mengubah pola pikir abdi negara, yang disalahartikan sebagai pengabdian kepada penguasa atau partai politik yang berkuasa, menjadi abdi masyarakat; (2) mengubah pola kerja birokrasi, yang selama ini dianggap sebagai kewajiban rutin yang linear menjadi lebih profesional; (3) memperbaiki hubungan birokrasi dengan masyarakat, yang selama ini jauh agar menjadi lebih dekat.

Banyaknya gagasan tentang model reformasi birokrasi mengingatkan kita tentang perlunya dibentuk suatu komisi reformasi birokrasi. Komisi ini terdiri dari para ahli dan praktisi birokrasi dan diberi tugas, seperti dikatakan Gerald Caiden (1976), untuk mengidentifikasi kelemahan-kelemahan dalam praktek birokrasi, membuat laporan dan mensosialisasikan temuan-temuan mereka, dan selanjutnya menyusun suatu rencana strategis untuk diajukan kepada pemerintah sebagai rekomendasi kebijakan reformasi. Dalam kaitan ini Miftah Thoha (2005) menambahkan bahwa kajian yang dilakukan komisi ini diharapkan dapat menghasilkan model kelembagaan birokrasi pemerintah yang berbeda dengan lembaga 'borokrasi' pemerintah orde baru. Dengan demikian, praktek-praktek korupsi dan perilaku feodal pejabat pemerintah dapat dirubah menjadi lebih bersih, transparan, profesional, partisipatif, inovatif, dan akuntabel.

Kondisi kepemimpinan birokrasi semacam inilah yang mengilhami penulisan artikel ini. Berdasarkan studi empirik dan kajian teori-teori yang terkait, artikel ini mencoba untuk membahas tentang transformasi kepemimpinan birokrasi, sebagai bagian dari upaya untuk melakukan reformasi birokrasi secara sistemik.

\section{Mengapa Transformasi Kepemimpinan Perlu Dilakukan?}

Alasan utama yang mendasari gagasan untuk melakukan transformasi kepemimpinan birokrasi adalah karena para pejabat birokrasi pemerintahan kita pada umumnya masih menerapkan model kepemimpinan transaksional (Weber, 1987), sementara berbagai permasalahan strategis perlu segera diselesaikan. Kita tahu, perkembangan global yang terjadi akhir-akhir ini telah menyebabkan semakin meningkatnya perubahan dalam berbagai dimensi kehidupan, perkembangan ilmu dan teknologi, persaingan ekonomi global, pengangguran tenaga terdidik, demasalisasi pasar, tuntutan masyarakat terhadap kualitas 
pelayanan publik, dan krisis keuangan yang hebat dan berkepanjangan (Osborne \& Plastrik, 1997).

Salah satu contoh perkembangan global tersebut yang berdampak langsung pada dimensi ekonomi dan sosial adalah kenaikan harga minyak mentah dunia yang terjadi tahun lalu. Meskipun pemerintah telah mengeluarkan kebijakan BSL, tak urung kenaikan harga BBM ikut mempertajam laju inflasi hingga mencapai $18 \%$ pada akhir tahun 2005. Laju pertumbuhan ekonomi tahun lalu pun, kata Mar'ie Muhammad, (2005) hanya mencapai 6\%, jauh di bawah negara-negara tetangga kita.

Lambatnya pertumbuhan perekonomian ini juga merupakan salah satu indikator penyempitan lapangan pekerjaan di Indonesia, karena selama ini pertumbuhan lebih besar didorong oleh konsums (Sugiyanto, 2005). Tidak mengherankan, kalau angka pengangguran semakin bertambah setiap tahun. Sejak tahun 1996 hingga tahun 2003, angka pengangguran terbuka terus bertambah rata-rata 5,5 persen per tahun, sedangkan angkatan kerja baru bertambah rata-rata 1,9 juta per tahun. Sementara itu, menurut hasil Survei Tenaga nasional BPS 2005, lapangan kerja hanya bertambah sedikitnya 200.000 untuk setiap pertambahan satu persen pada pertumbuhan ekonomi. Pada periode tahun 2004-2006, menurut laporan Bappenas (2005), pertambahan angka pengangguran terbuka rata-rata mencapai 9,5 persen per tahun, sedangkan angkatan kerja baru bertambah 1,9 juta per tahun. Dengan demikian, berarti jumlah pengangguran di Indonesia saat ini, baik pengangguran absolut maupun under employment, telah mencapai 42,1 juta orang.

Krisis ekonomi dan sosial seperti dicontohkan di atas, serta krisis-krisis lain pada berbagai dimensi kehidupan berbangsa dan bernegara, merupakan isyarat betapa birokrasi pemerintahan kita kurang mampu mengantisipasi dan menanggulangi perubahan global. Salah satu sebabnya adalah karena sistem birokrasi pemerintahan kita masih mengikuti konsep birokrasi Weber, yang memiliki karakteristik sebagai berikut: (a) pelaksanaan berbagai kegiatan reguler diatur secara jelas dan dianggap sebagai kewajiban untuk mencapai tujuan organisasi; (b) kelembagaan diatur secara hierarkis, unit yang lebih rendah berada di bawah pengawasan unit yang lebih tinggi; (c) standar pelaksanaan kerja diterapkan secara ketat dan spesifik; (d) pola karir diatur melalui sistem senioritas atau prestasi, atau kombinasi antara keduanya; dan (d) kepemimpinan dilaksanakan secara impersonal, tanpa kebencian atau empati, tanpa entusiasme atau afeksi (Weber, 1987). Penerapan secara per se konsep tersebut tentu akan menghasilkan suatu lembaga hierarki yang penuh dengan jenjang jabatan, cara bekerja yang lamban, dan tata aturan yang kaku dan berliku-liku.

Oleh karena itu, wajarlah kalau lembaga birokrasi pemerintahan seringkali diartikan sebagai officialdom atau kerajaan pejabat, yang penuh dengan pimpinan unit yang bekerja pada tatanan hierarki dengan kompetensi yang spesifik. Di dalam lembaga terdapat yurisdiksi dimana setiap pejabat memiliki official duties, sementara komunikasi dilakukan secara formal dengan menggunakan dokumen tertulis (Fauziah, 2006). Karena kekuasaan hierarkis yang diperoleh, pola kepemimpinan birokrasi yang diikuti para pejabat pun cenderung berubah menjadi kepemimpinan feodal (Weber, 1947). Seperti seorang raja, pimpinan birokrasi 
semacam ini mendasarkan hubungan atasan-bawahan (patron-client) pada loyalitas, nepotisme, dan politik.

Sayangnya, justru karaketristik semacam inilah yang banyak dijumpai pada pemimpin birokrasi pemerintah kita, terutama pada era Orde Baru. Kekakuan dalam hierarki, tuntutan loyalitas pada pegawai, interaksi yang penuh nepotisme, dan kebijakan yang diwarnai politik banyak dipraktekkan. Proses pengambilan keputusan yang terlalu hierarkis juga banyak mewarnai kegiatan sehari-hari. Pegawai banyak berpangku tangan karena harus menunggu petunjuk, perintah dan persetujuan dari atasan dalam melakukan suatu pekerjaan. Dampak dari malpraktik ini adalah hilangnya daya kreatifitas, inisiatif dan inovasi pegawai. Prinsip-prinsip profesionalitas, efektivitas dan efisiensi yang diharapkan muncul dalam kinerja birokrasi pun berubah menjadi ketidakmampuan, kelambanan, dan pemborosan.

Akibatnya dapat ditebak. Lembaga birokrasi tidak berdaya menghadapi perubahan global yang mucul menjelang pergantian abad lalu. Berbagai kebijakan pemerintah yang seharusnya menjadi pedoman kinerja birokrasi pun hanya menjadi wacana. Good governance yang diharapkan menjadi strategic solution krisis globalisasi akhirnya hanya menjadi konsep tematik sambutan para pejabat. Visi dan misi dianggap komitmen pimpinan belaka karena tak pernah diinternalisasikan, sehingga mayoritas pegawai tidak tahu, memahami, apalagi mendukung, keberhasilan pencapaiannya. Quo vadis birokrasi? ${ }^{2}$

Maka, sungguh tepat langkah langkah Presiden Yudoyono yang menjadikan reformasi birokrasi sebagai salah satu program yang diprioritaskan dalam pemerintahannya. Sebagai 'a means by which government rules', (Kilcullen, 1966) peran birokrasi memang sangat signifikan dalam memperbaiki kondisi kehidupan bangsa dan negara yang sedang carut-marut ini. Namun hingga saat ini masih belum jelas benar grand strategy yang akan diterapkan pemerintaha dalam melakukan reformasi birokrasi. Komisi reformasi birokrasi pun belum tampak tanda-tanda akan dibentuk. Padahal diberbagai negara yang melakukan reformasi birokrasi peran komisi semacam itu sangat strategis.

Misalnya PM Inggris Margareth Thatcher, pada awal tahun 1990an membentuk sebuah komisi birokrasi untuk merumuskan program perbaikan pelayanan publik The Next Steps. Demikian juga Presiden AS Bill Clinton, pada pertengahan tahun 1990an merangkul David Osborne dan menunjuk Wapres Al Gore untuk memimpin proyek reformasi birokrasi Reinventing Government. Jauh sebelumnya, Presiden AS yang ke-28, Woodraw Wilson, membentuk komisi reformasi untuk melakukan perbaikan birokrasi pemerintahanya.

Di Indonesia, ketika berniat untuk melakukan reformasi birokrasi pada tahun 1950an, Presiden Sukarno mendatangkan beberapa dari AS, seperti Allan Rankin, Howard Jones, dan Eduard Lichfield, sebagai konsultan bagi komisi reformasi yang dipimpin PM Ir. H. Djuanda. Demikian pula Presiden Soeharto, pada periode kedua jabatannya mengumpulkan para akademisi untuk menyusun strategi reformasi birokrasi. Meskipun lembaga birokrasi yang terbentuk cenderung bersifat sentralistik, monopolistik, memiliki kekuasaan (power driven) dan diskresi dalam menentukan kebijakan, dan dengan akuntabilitas rendah yang rentan korupsi (Klitgaard, 1996), harus diakui bahwa komisi berhasil membentuk kabinet yang stabil, kuat, dan efektif, tanpa sekalipun pernah mengalami reshuffle (Thoha, 2005).

Suatu kajian yang cukup komprehensif tentang reformasi birokrasi pernah dilakukan PKP2A III dalam sebuah seminar nasional. Lihat: Tri Widodo W. Utomo (et.al.), Quo Vadis Reformasi Birokrasi: Sebuah Refleksi Perjalanan 7 Tahun Birokrasi Indonesia, Samarinda, PKP2A III, 2005. 
Permerintah memang tengah berupaya melakukan perbaikan lembaga birokrasi melalui penyusunan UU Pelayanan Publik. Demikian pula berbagai ahli dan praktisi telah banyak mengemukakan konsep-konsep reformasi untuk memperbaiki kinerja birokrasi dengan berbagai pendekatan. Akan tetapi, upaya parsial semacam ini tentu kurang efektif, walau bukan berarti mubazir. Reformasi birokrasi harus dilakukan secara sistemik karena permasalahannya pun sudah semakin kompleks. Adalah tugas komisi reformasi birokrasi, seandainya nanti terbentuk, untuk mengumpulkan dan mengalisis konsep-konsep dari berbagai narasumber tersebut. Dengan demikian, suatu grand strategy reformasi birokrasi yang sistemik dapat disusun berdasarkan pada orientasi pendekatan yang digunakan para narasumber, misalnya pendekatan kelembagaan, ketatalaksanaan, kepegawaian, kultural, atau kepemimpinan birokrasi seperti yang akan dipaparkan dalam kajian/tulisan ini.

\section{Kondisi Birokrasi Saat Ini}

Ketika merumuskan konsep birokrasi pada awal abad ke-20, Max Weber (18641920) sebenarnya berharap bahwa 'birokrasi dapat menjadi organisasi pemerintah yang mampu melayani masyarakat secara adil, obyektif, profesional, efektif dan efisien.' Agar dapat mencapai tujuan tersebut, maka 'organisasi birokrasi tidak boleh memihak kepada kekuatan politik tertentu, diatur secara hirarkis dimana organisasi yang lebih rendah berada di bawah pengawasan organisasi yang lebih tinggi, memiliki pembagian kerja yang jelas dengan pedoman yang standar, dan dipimpin oleh pejabat secara impersonal, sine ira et studio, tanpa kebencian atau kesenangan, tanpa entusiasme atau afeksi' (Kilcullen, 1962),

Apabila konsep birokrasi Weberian dihubungkan dengan kondisi saat, ada dua aspek yang terasa kontradiktif. Di satu pihak, tujuan birokrasi sesuai benar dengan tuntutan masyarakat terhadap pelayanan publik yang adil, obyektif, profesional, efektif dan efisien. Namun di pihak lain, metode yang ditempuh untuk mencapai tujuan yang berorientasi pada organisasi hierarki, pengawasan impersonal, dan pedoman yang kaku, tampaknya tidak sesuai lagi dengan kondisi saat ini yang penuh perubahan dan memerlukan fleksibilitas tinggi.

Apalagi kalau diingat bahwa iklim birokrasi kita saat ini masih diwarnai berbagai malpraktik yang berkembang dan membudaya selama 32 tahun masa pemerintahan Presiden Soeharto, yang berorientasi pada sentralistik, monopolistik, power driven, dan akuntabilitas rendah. Tidak heran kalau stigma yang melekat pada birokrasi selama ini selalu identik dengan pelayanan publik berkualitas rendah yang penuh korupsi, kolusi dan nepotisme. Tidak aneh pula kalau hasil-hasil survei dari the Political and Economic Risk Consultancy dan The World Competitiveness terbitan Institute for Management Development (IMD) selalu menempatkan kinerja birokrasi Indonesia pada posisi juru kunci (Anwaruddin, 2005).

Dalam bidang pelayanan publik, masyarakat masih mengeluh tentang masih adanya diskriminasi pelayanan yang didasarkan pada hubungan pertemanan, afiliasi politik, etnis, bahkan agama, serta profesionalitas pelayanan yang tercermin pada inefektivitas dan inefisiensi waktu, biaya, dan cara pelayanan (Pusat Studi Kependudukan UGM, 2002). Demikian juga yang terjadi dengan isu korupsi, yang pemberantasannya menjadi salah satu prioritas utama pemerintahan Presiden Yudoyono.

Budaya korupsi yang tumbuh subur selama Pemerintahan Presiden Soeharto ternyata belum berakhir. Bahkan sebaliknya, dengan mulai diterapkannya kebijakan otonomi daerah, dimulai pula desentralisasi korupsi di seantero negeri. Korupsi kini tidak lagi didominasi birokrasi pusat, seperti yang terjadi pada era Orde Baru, tetapi sudah merambah 
ke lingkungan pemerintah Daerah. Menurut laporan Indonesia Corruption Watch, kasus korupsi sepanjang tahun 2004 saja mencapai 125 orang di tubuh DPRD, Kepala Daerah 84, aparat Pemda 57, pimpinan proyek 36, direktur BUMD/BUMN 36, Kepala Dinas 25, aparat Departemen 15, Aparat Kejaksaan 13, Pengusaha 12, Sekretaris Daerah 7, Aparat Desa 6, Polisi 5, Pengelola Pendidikan 5, dan dari sektor lainnya sebanyak 25 orang. Daftar ini akan semakin panjang bila disertakan pula kondisi sepnajang tahun 2005.

Dengan demikian, wajar jika hasil survei Transparency International tujuh tahun terakhir (1998-2005) selalu menempatkan Indonesia pada posisi sepuluh besar negara-negara terkorup di dunia, sebagaimana dapat dilihat pada tabel di bawah ini.

Tabel 1

\section{Posisi Transparansi Indonesia (1998-2005)}

\begin{tabular}{|c|c|c|}
\hline Tahun & Nilai CPI & Posisi Transparansi Indonesia \\
\hline 1998 & 2.0 & Urutan ke-80 dari 85 negara \\
\hline 1999 & 1.7 & Urutan ke-96 dari 98 negara \\
\hline 2000 & 1.7 & Urutan ke-85 dari 90 negara \\
\hline 2001 & 1.9 & Urutan ke-88 dari 91 negara \\
\hline 2002 & 1.9 & Urutan ke-96 dari 122 negara \\
\hline 2003 & 1.9 & Urutan ke-122 dari 133 negara \\
\hline 2004 & 2.0 & Urutan ke-137 dari 145 negara \\
\hline 2005 & 2.2 & Urutan ke-140 dari 159 negara \\
\hline
\end{tabular}

Sumber: Adaptasi Transparency International (1998-2005)

Pada tahun 2005 lalu, posisi Indonesia masih berada pada urutan keenam, atau ke140 di antara 159 negara-negara terkorup sedunia, bersama-sama Azerbaijan (137), Kamerun (138), Ethiopia (139), Iraq (141) Liberia (142), dan Uzbekistan (143). Dengan capaian tersebut, berarti Indonesia menempati urutan kelima di antara negara-negara terkorup di kawasan Asia setelah Bangladesh, Myanmar, Pakistan dan Iraq. Dalam posisi ke-158 Bangladesh juga menduduki posisi pertama bersama-sama peringkat tertinggi Chad (159), seperti terlihat pada tabel di bawah ini.

Tabel 2

Indeks Persepsi Korupsi (CPI) Tahun 2005

\begin{tabular}{|l|c|c|c|}
\hline \multicolumn{1}{|c|}{ Nama Negara } & $\begin{array}{c}\text { Ranking } \\
\text { Transparansi }\end{array}$ & $\begin{array}{c}\text { Ranking } \\
\text { Korupsi }\end{array}$ & $\begin{array}{c}\text { Nilai CPI } \\
\mathbf{2 0 0 5}\end{array}$ \\
\hline Chad, Bangladesh & 159 & 1 & 1.7 \\
\hline Turkmenistan, Myanmar, Haiti & 157 & 2 & 1.8 \\
\hline
\end{tabular}




\begin{tabular}{|l|c|c|c|}
\hline $\begin{array}{l}\text { Nigeria, Guinea Equatorial, Cote } \\
\text { d'Ivoire }\end{array}$ & 154 & 3 & 1.9 \\
\hline Angola & 151 & 4 & 2.0 \\
\hline $\begin{array}{l}\text { Tajikistan, Sudan, Somalia, } \\
\text { Paraguay, Pakistan, Kenya, Rep } \\
\text { Demokrasi Congo }\end{array}$ & 150 & 5 & 2.1 \\
\hline $\begin{array}{l}\text { Uzbekistan, Liberia, Iraq, } \\
\text { Indonesia, Ethiopia, Kamerun, } \\
\text { Azerbaijan }\end{array}$ & 143 & 6 & 2.2 \\
\hline
\end{tabular}

Sumber: Adaptasi dari Transparency International (2005)

Data di atas sebenarnya menunjukkan kemajuan indeks korupsi kita pada tahun 2005 dibanding tahun-tahun sebelumnya. Namun perkembangan tersebut tidak signifikan, yakni hanya $0,6 \%$ per tahun dibanding dengan pertumbuhan ekonomi yang hanya mencapai $6 \%$, per tahun. Apalagi kalau mengingat bahwa laju inflasi pada akhir 2005 telah mencapai $18 \%$. Dampak dari kondisi ini adalah semakin terpuruknya wajah perekonomian kita di mata dunia. Tidak sedikit investor asing yang mengalihkan modalnya ke negara-negara tetangga, seperti Thailand dan Vietnam, karena dianggap lebih transparan.

Dengan demikian, semakin terasa urgensi reformasi birokrasi di Indonesia. Perbaikan yang telah dimulai pemerintah melalui penerbitan UU Pelayanan Publik diharapkan diikuti dengan revisi di sektor lain. Agar lebih komprehensif, reformasi birokrasi sebaiknya dilakukan secara sistemik berdasarkan pada analisis di dalam tubuh birokrasi. Hal ini seyogyanya dilakukan oleh suatu komisi reformasi birokrasi, yang selanjutnya ditugaskan untuk menyusun langkah-langkah yang strategis. Melalui reformasi ini, diharapkan dapat terwujud birokrasi yang mampu melaksanakan pelayanan publik secara adil, obyektif, profesional, efektif dan efisien sebagaimana dituntut masyarakat.

\section{Modernisasi Birokrasi}

Telah diuraikan di atas, bahwa pola kerja birokrasi model Weber pada hakekatnya berorientasi pada hierarki organisasi, kepemimpinan impersonal, dan pedoman kerja yang kaku. Dalam implementasi sehari-hari, konsep tersebut terurai menjadi karakteristik umum kinerja birokrasi pemerintahan sebagai berikut: (1) kekuasaan atasan bersifat mutlak; (2) pembagian kerja sesuai tugas pokok dan fungsi; (3) koordinasi langsung ditangani oleh atasan; (4) pekerjaan dilakukan secara rutin, monoton, dan tanpa makna; (5) profesionalitas kerja tidak diutamakan; (6) pegawai hanya memiliki satu bidang keahlian; dan (7) individualitas sangat menonjol dalam pelaksanaan kerja.

Gambaran kinerja birokrasi seperti di atas mungkin cocok pada beberapa dekade yang lalu, ketika kondisi pemerintahan cukup stabil, masyarakat mudah diatur, dan pekerjaan masih sederhana. Tetapi pada era yang penuh persaingan dan perubahan yang fluktuatif ini, pola kerja birokrasi tradisional menjadi terlalu lamban, tidak responsif, dan tidak mampu mengatasi beragam tantangan. Padahal konsep awal perumusan birokrasi adalah 
pembentukan organisasi pemerintah yang memiliki kompetensi dalam menyelenggarakan pelayanan publik secara adil, obyektif, profesional, efektif dan efisien, seperti juga diharapkan oleh masyarakat.

Jelas, reformasi memang harus dilakukan terhadap kinerja birokrasi transaksional agar sesuai dengan tujuan semula, tuntutan masyarakat, dan perkembangan zaman. Dengan demikian, arah reformasi adalah merubah kinerja yang selama ini umumnya dilakukan menjadi kinerja yang diharapkan masyarakat dan sesuai perkembangan zaman. Dalam hubungan ini, tampaknya kita perlu menyimak pendapat Gifford \& Pichot (1993) yang menyarankan arah yang seharusnya ditempuh oleh lembaga birokrasi sebagai berikut: (1) Kekuasaan berorientasi pada kepentingan masyarakat; (2) Pembagian kerja berdasarkan proyek atau program; (3) Koordinasi berlangsung di antara sesama kolega; (4) Kreativitas, inovasi dan kepedulian diutamakan; (5) Profesionalitas, efektivitas dan efisiensi diutamakan; (6) Pegawai memiliki beragam keahlian; dan (7) Pekerjaan dilaksanakan secara bersamasama dalam kelompok atau tim kerja. Untuk lebih menjelaskan arah reformasi birokrasi, berikut ini dibandingkan kinerja birokrasi transaksional yang dirumuskan Weber dan kinerja birokrasi transformasional yang diharapkan oleh masyarakat.

Tabel 3

\section{Arah Perubahan Kinerja Birokrasi}

\begin{tabular}{|c|c|c|}
\hline Kinerja Birokrasi Transaksional & \multirow{3}{*}{$\begin{array}{l}\rightarrow \\
\Rightarrow\end{array}$} & Kinerja Birokrasi Transformasional \\
\hline Kekuasaan atasan bersifat mutlak & & Kekuasaan berorientasi pada kepentingan masyarakat \\
\hline Pembagian kerja sesuai tupoksi & & Pembagian kerja berdasarkan proyek atau program \\
\hline Koordinasi langsung oleh atasan & \multirow{2}{*}{$\begin{array}{l}\rightarrow \\
\rightarrow\end{array}$} & Koordinasi berlangsung di antara sesama kolega \\
\hline Pekerjaan monoton, dan tanpa makna & & Kreativitas, inovasi dan kepedulian diutamakan \\
\hline Profesionalitas kerja tidak ditekankan & \multirow{3}{*}{$\begin{array}{l}\rightarrow \\
\rightarrow \\
\rightarrow\end{array}$} & Profesionalitas, efektivitas dan efisiensi diutamakan \\
\hline Pegawai memiliki satu bidang keahlian & & Pegawai memiliki beragam keahlian \\
\hline Individualitas dalam pelaksanaan kerja & & Pekerjaan dilaksanakan secara kelompok atau tim. \\
\hline
\end{tabular}

Sumber: Adaptasi dari Gifford and Pinchot, Elizabeth (1993)

Akan tetapi, untuk mengatasi krisis multi-dimensi yang telah melanda negeri selama sewindu, perubahan arah tidak cukup dilakukan terhadap pola kerja tetapi juga pada organisasi birokrasi secara keseluruhan. Organisasi birokrasi yang selama ini terkesan formal dan tertutup mesti lebih membuka diri dengan menanamkan jiwa kewirausahaan dalam tindak dan kegiatannnya. Kita tahu, David Osborne \& Ted Gaebler (1992) menyusun konsep populer kewirausahaan birokrasi yang juga telah diterapkan di beberapa negara lain.

Konsep kewirausahaan birokrasi terdiri atas sepuluh prinsip sebagai berikut: (1) mengarahkan dan bukan melaksanakan semua pekerjaan, (2) memberdayaan masyarakat, (3) menciptakan persaingan untuk memberikan pelayanan yang terbaik, (4) menggerakkan 
organisasi berdasarkan pada misi dan bukan pada aturan buatan sendiri, (5) menghasilkan pendanaan dan bukan menunggu anggaran, (7) berorientasi pada kepentingan warga negara pembayar pajak, (6) menghemat dan bukan hanya menghabiskan anggaran, (8) mencegah daripada mengobati permasalahan, (9) mengelola kerja kelompok dan bukan kerja individu, dan (10) memperhatikan kemauan pasar atau publik

Dalam hubungan ini, perlu dipertimbangkan pula konsep George Frederickson (1977) ketika menyusun arah organisasi birokrasi yang berorientasi pada kepentingan publik dibandingkan dengan sistem birokrasi transaksional sebagai berikut :

Tabel 4

\section{Arah Perubahan Sistem Birokrasi}

\begin{tabular}{|c|c|c|}
\hline Sistem Birokrasi Transaksional & \multirow{3}{*}{$\begin{array}{l}\rightarrow \\
\rightarrow\end{array}$} & Sistem Birokrasi Modern \\
\hline Melakukan pekerjaan sendiri & & Mengarahkan pelaksanaan pekerjaan \\
\hline Memberikan pelayanan langsung & & Memberdayakan masyarakat \\
\hline Menerapkan sistem monopoli pasar & \multirow{3}{*}{$\begin{array}{l}\rightarrow \\
\rightarrow \\
\rightarrow\end{array}$} & Menciptakan persaingan \\
\hline Kegiatan berdasarkan aturan & & Kegiatan berorientrasi pada misidan visi \\
\hline Menunggu anggaran & & Menghasilkan anggaran \\
\hline Digerakkan oleh atasan & \multirow{2}{*}{$\begin{array}{l}\rightarrow \\
\rightarrow\end{array}$} & Digerakkan oleh kepentingan pelanggan \\
\hline Berorientasi pada pengeluaran & & Berorientasi pada penghasilan \\
\hline Mengatasi masalah & $\rightarrow$ & Mencegah timbulnya masalah \\
\hline Menerapkan mekanisme hierarki & $\rightarrow$ & Mekanisme kerja kelompok/partisipasi \\
\hline Berorientasi kelembagaan & $\rightarrow$ & Berorientasi pada kebutuhan pasar \\
\hline
\end{tabular}

Sumber: Adapatasi dari Frederickson, George (1977)

Melakukan perubahan arah organisasi birokrasi seperti gambaran di atas tentu tidak gampang, mengingat luas dan kompleksnya permasalahan organisasi birokrasi kita. Pekerjaan besar seperti itu mesti dilakukan secara incremental-dan bukan radical, melalui beberapa tahapan. Yang pertama harus diketahui adalah menganalisis karakteristik permasalahan dari sistem birokrasi yang selama ini diterapkan, yang dapat dilakukan oleh sebuah komisi reformasi birokrasi sebagaimana telah didiskusikan sebelumnya. Hasil analisis ini kemudian dibandingkan membandingkan dengan arah perubahan yang diharapkan, yakni organisasi birokrasi yang berorientasi pada kewirausahaan.

Untuk dapat melakukan dua pekerjaan besar tersebut-yakni merubah arah kinerja dan sistem organisasi birokrasi, tentu diperlukan pimpinan birokrasi yang mampu '... 
mendorong semangat, merubah nilai, dan memperhatikan kebutuhan karyawan melalui kewenangan dan pengaruh yang dimilikinya, untuk bersama-sama mencapai tujuan organisasi.' (Starch, 1943; Terry, 1960; Fiedler, 1869; Stogdill, 1977; dan Bass, 1990). Karakteristik seperti inilah yang mendasari konsep transformasi kepemimpinan birokrasi.

\section{Kepemimpinan Birokrasi}

Kepemimpinan birokrasi barangkali dapat didefiniskan sebagai suatu proses mempengaruhi para pegawai untuk menyelesaikan suatu pekerjaan, dan mengarahkan organisasi agar lebih kompak dan kondusif, dengan cara menerapkan konsep, nilai, etika, karakter, pengetahuan dan ketrampilan. Berdasarkan pengertian ini, seorang atasan yang hanya menggunakan kewenangan untuk menyelesaikan tugas dan tujuan tertentu belum dapat disebut pemimpin, tetapi hanya sekedar pimpinan. Pemimpin dapat mempengaruhi para pegawai untuk mencapai tujuan, sementara pimpinan hanya mampu memberikan perintah.

Di Indonesia, fenomena pimpinan yang bukan pemimpin masih banyak ditemukan pada organisasi birokrasi pemerintahan. Hal ini terjadi karena sistem promosi kepegawaian birokrasi kita, seperti diindikasikan Kwik Kian Gie (2003), masih belum sepenuhnya berdasarkan keahlian (merit-based promotion), tetapi masih diwarnai oleh hubungan kepartaian (spoil) atau keluarga (nepotism), sistem karir (career), prestasi kerja (performance), atau bahkan perlindungan (patronage) (Sianturi, 1984). Jadi jangan heran, kalau pada suatu lembaga pemerintah ditemukan seorang kepala unit yang hanya bisa memerintahkan ini-itu, tanpa tahu bagaimana seharusnya memimpin pegawainya.

Pimpinan birokrasi semacam ini umumnya diangkat berdasarkan pada senioritas (seniority-based promotion), baik dari sisi kepegawaian (DUP) maupun kepangkatan (DUK), bahkan terkadang tanpa kualifikasi kepemimpinan. Dalam hubungan inilah, akhirnya muncul empat jenis perilaku kepemimpinan, terutama apabila dilihat dari persepsi kemampuan dalam memimpin dan kemauannya untuk berkembang, yaitu: (1) pemimpin yang tidak mampu memimpin, dan tidak mau berkembang, (2) pemimpin yang tidak mampu memimpin, tetapi mau berkembang, (3) ) pemimpin yang mampu memimpin, tetapi tidak mau berkembang, dan (4) pemimpin yang mampu memimpin, dan mau berkembang (Hensey \& Blachard, 1982).

Pola kepemimpinan keempat inilah yang diharapkan dimiliki oleh setiap pimpinan birokrasi agar dapat memberdayakan pegawai dan mengarahkan organisasi melalui penerapan konsep, nilai, etika, karakter, pengetahuan dan ketrampilan. Secara sederhana, pola perilaku kepemimpinan di atas dapat digambarkan sebagai berikut:

Tabel 5

Pola Perilaku Kepimpinanan Organisasi Birokrasi

\begin{tabular}{|l|l|l|l|}
\hline Pola & $\begin{array}{l}\text { Kemampuan } \\
\text { memimpin }\end{array}$ & $\begin{array}{l}\text { Kemauan } \\
\text { berkembang }\end{array}$ & $=\begin{array}{l}\text { Perilaku } \\
\text { kepemimpinan }\end{array}$ \\
\hline 1 & - & - & $=$ \\
\hline 2 & + & - & $=$ \\
\hline 3 & - & + & $=$ \\
\hline 4 & + & + & $=$ \\
\hline
\end{tabular}

Sumber: Adaptasi dari Hensey and Blanchard, 1982 (1977) 
Isu banyaknya pimpinan yang bukan pemimpin dalam organisasi birokrasi tidak terlepas dari pemahaman kita tentang konsep kepemimpinan menurut teori manajemen klasik dan rumusan birokrasi Weberian. Paradigma kepemimpinan modern, yang memasukkan unsur motivasi dan komunikasi dalam perilaku kepemimpinan, baru muncul pada periode tahun 1980an melalui konsep kepemimpinan transformasi oleh James McGregor Burns (1978), dan selanjutnya dikembangkan oleh Bernard Bass (1985) dan pakar kepemimpinan lainnya.

Dalam teori manajemen klasik, tugas seorang pimpinan memang hanya ditekankan pada pelaksanaan fungsi-fungsi manajemen dan memanfaatkan sumber-sumber daya yang ada dalam organisasi. Konsep kepemimpinan klasik ini terus berkembang dengan semakin maraknya pendidikan ilmu administrasi dan manajemen. Fungsi-fungsi manajemen George Terry (1977)_-Planning, Organizing, Actuating and Controlling (POAC), dan sumberdaya organisasi 6M (Man, Money, Machines, Methods, Materials, and Market) didayagunakan dan dimanfaatkan para pimpinan, seperti diingatkan oleh Keith Davis (1967), tanpa memikirkan bagaimana cara mempengaruhi, memotivasi dan membimbing karyawan untuk bersama-sama mencapai tujuan organisasi.

Oleh karena itu, setelah memahami pola perilaku kepemimpinan di atas, pimpinan birokrasi yang ingin berkembang menjadi pemimpin di instansinya seharusnya juga memahami perbedaan antara tugas dan tanggung-jawab seorang pimpinan dan apa yang harus dilakukan seorang pemimpin dalam mencapai tujuan organisasinya. Dalam hubungan ini, Warren Bennis (dalam Shelton, 1997) menguraikan perbedaan antara pimpinan (manager) dan pemimpin (leader) dalam perspektif organisasi modern berdasarkan pada pola perilaku kepemimpinan dalam mencapai tujuan organisasi sebagai berikut:

Tabel 6

Perbedaan Fungsi Pimpinan dan Peminpin Organisasi Birokrasi

\begin{tabular}{|c|}
\hline Pimpinan \\
\hline Mengatur jalannya organisasi \\
\hline Jabatan diperoleh melalui promosi \\
\hline $\begin{array}{r}\text { Selalu berusaha untuk mempertahankan } \\
\text { jabatan }\end{array}$ \\
\hline Pengawasan pegawai lebih diutamakan \\
\hline $\begin{array}{r}\text { Orientasi pada pencapaian tujuan jangka } \\
\text { pendek }\end{array}$ \\
\hline $\begin{array}{r}\text { Bertanya bagaimana \& kapan tugas } \\
\text { diselesaikan }\end{array}$ \\
\hline $\begin{array}{r}\text { Komunikasi bersifat atas-bawah (top- } \\
\text { down) }\end{array}$ \\
\hline Menerima status quo secara apa adanya \\
\hline $\begin{array}{r}\text { Melaksanakan perintah atasan tanpa } \\
\text { reserve }\end{array}$ \\
\hline Mengerjakan tugas-tugas dengan benar \\
\hline
\end{tabular}

\begin{tabular}{|l|}
\hline Pemimpin \\
\hline $\begin{array}{l}\text { Mengarahkan organisasi untuk mencapai } \\
\text { tujuan }\end{array}$ \\
\hline Pengakuan diperoleh dari lingkungannya \\
\hline $\begin{array}{l}\text { Selalu berusaha untuk mengembangkan } \\
\text { organisasi }\end{array}$ \\
\hline Menanamkan kepercayaan kepada pegawai \\
\hline $\begin{array}{l}\text { Orientasi pada pencapaian visi dan misi } \\
\text { organisasi }\end{array}$ \\
\hline $\begin{array}{l}\text { Bertanya apa \& mengapa tugas harus } \\
\text { dilaksanakan }\end{array}$ \\
\hline $\begin{array}{l}\text { Komunikasi dilakukan ke semua arah } \\
\text { (multi-level) }\end{array}$ \\
\hline $\begin{array}{l}\text { Merubah status quo sesuai situasi dan } \\
\text { kondisi }\end{array}$ \\
\hline $\begin{array}{l}\text { Menjadi dirinya sendiri dalam } \\
\text { melaksanakan perintah }\end{array}$ \\
\hline Mengerjakan tugas-tugas yang benar \\
\hline
\end{tabular}

Sumber: Adapatasi dari Bennis, Warren (1997) 
Di samping pengaruh teori manajemen klasik di atas-yang berujung pada perbedaan pimpinan dan pemimpin, kepemimpinan birokrasi juga diwarnai oleh konsep organisasi model Weber yang diatur secara hirarkis, dengan pembagian kerja yang jelas, standarisasi pedoman kerja, dan pengawasan impersonal. Wajarlah bila kepemimpinan birokrasi pun cenderung berorientasi pada kekuasaan secara rasional, legal dan hierarkis, serta pengawasan pelaksanaan kerja. Burns (1978) dan Bass (1985) menambahkan, bahwa kepemimpinan birokrasi bersifat transaksional antara kekuasaan dan layanan pegawai. Jadi, seperti dikritik oleh Mark Homrig (2005), seperti mekanisme jual-beli saja, pekerjaan ditukar dengan gaji, jabatan dengan loyalitas, sumbangan dengan tender, dsb.

Model kepemimpinan semacam itu memang sesuai dengan lingkungan lembaga birokrasi yang penuh dengan peraturan, baik normatif maupun teknis. Pedoman administrasi, kontrak kerja, keputusan, dan petunjuk teknis semuanya rapi didokumentasikan secara tertulis. Pegawai dididik untuk mentaati aturan, loyal kepada perintah atasan dalam kapasitasnya sebagai karyawan. Hubungan pimpinan-pegawai bersifat formalitas, terbatas pada pelaksanaan pekerjaan saja. Ruang gerak pegawai pun sangat terbatas. Penghasilan dan pensiun sudah diatur secara tetap, dan jumlahnya tergantung pada pangkat dan golongan pegawai dalam hierarki kepegawaian, atau seperti dikritik Kwik Kian Gie (2003): Pintar Goblik Penghasilan Sama (PGPS). Menjadi pegawai lembaga birokrasi berarti teken kontrak sampai pensiun. Pegawai tidak berhak atas jabatan karena sistem promosi umumnya berdasarkan pada senioritas dalam kepagawaian dan kepangkatan.

Model kepemimpinan birokrasi, menurut Weber (1947), banyak diterapkan di organisasi keagamaan, rumah sakit, perusahaan bisnis berskala kecil maupun multi-nasional, militer, dan tentu saja instansi pemerintah. Sisi positif dari model kepemimpinan birokrasi tradisional ini terletak pada efisiensi di dalam pelaksanaan kerja karena kejelasan pembagian kerja sesuai dengan tugas pokok dan fungsi masing-masing staf dalam organisasi, standarisasi pedoman dan aturan kerja, dan konsistensi terhadap tata aturan yang telah ditetapkan.

Di samping itu, kepemimpinan birokrasi juga menjamin pencapaian tujuan jangka pendek dan kemudahan dalam pengawasan dan pengelolaan pegawai. Sementara sisi negatifnya adalah kepemimpinan yang berorientasi pada kekuasaan yang hierarkis, tiadanya pemberdayaan pegawai dan pembagian kewenangan dalam pengambilan keputusan, kondisi yang kurang kondusif karena penerapa komunikasi top-down dan formalitas hubungan antara atasan dan bawahan, dan loyalitas yang kadang berlebihan kepada atasan.

Weber sendiri (1947), sewaktu merumuskan tiga konsep kepemimpinan-charismatic (transformer), bureaucratic (transactional), feudal (traditional), mengingatkan bahwa karena kekuasaan hierarkis yang diperolehnya maka kepemimpinan birokrasi (transactional) cenderung untuk berubah menjadi kepemimpina feodal (traditional). Perilakunya pun berubah menjadi seperti seorang pangeran, yang menuntut loyalitas total dari anak-buahnya, mengembangkan sistem nepotisme, dan berorientasi pada politik kekuasaan. 
Berdasarkan diskusi di atas dan referensi dari berbagai sumber, baik teoritik maupun empirik, di bawah ini tersusun sepuluh karakteristik kepemimpinan birokrasi (transaksional) dalam lingkup organisasi pemerintahan sebagai berikut:

1. Berdasarkan transaksi: Kepemimpinan birokrasi bertindak atas dasar transaksi atau pertukaran antara jabatan dan kinerja, gaji dan pekerjaan, kerja keras dan bonus, dsb.

2. Kejelasan aturan: Pedoman dan aturan pelaksanaan tugas dan pekerjaan disusun secara jelas dan ditetapkan untuk ditaati oleh setiap pegawai..

3. Orientasi pada pengawasan: Mengawasi dan memantau tugas dan pekerjaan secara ketat dalam rangka mencapai tujuan jangka pendek.

4. Anti perubahan: Menolak setiap perubahan yang berasal dari luar sistem organisasi karena khawatir akan merusak tatanan kelembagaan yang telah ditetapkan.

5. Orientasi pada jabatan dan kekuasaan: Mengembangkan budaya kekuasaan, loyalitas pada atasan, hierarki hubungan atasan-bawahan, dan komunikasi bottom-up

6. Fokus pada pekerjaan: Mengarahkan pegawai untuk fokus pada penyelesaian tugas dan pekerjaan, sehingga mereka tidak memiliki kesempatan untuk mengembangkan diri.

7. Kewenangan atasan mutlak: Tidak ada pemberdayaan pegawai karena kewenangan untuk mengambil keputusan mutlak pada pimpinan.

8. Pemasungan kreatifitas pegawai. Pegawai diatur dalam pelaksanaan tugas dan pekerjaan, sehingga mereka tidak dapat mengembangkan kreatifitas dan inovasi.

9. Individualitas kerja: Kerja sama antar pegawai tidak dianjurkan, sehingga muncul persaingan tak-sehat dan saling curiga-mencurigai di antara mereka.

10. Disharmoni organisasi: Hierarki kekuasaan, formalitas hubungan, komunikasi bottomup, dan absennya kerjasama antara pegawai mengakibatkan ketidak-kondusifan organisasi..

Model kepemimpinan birokrasi seperti itu banyak diterapkan pada organisasi keagamaan, rumah sakit, perusahaan bisnis berskala kecil maupun multi-nasional, militer, dan tentu saja instansi pemerintah. Sisi positif dari model kepemimpinan birokrasi tradisional ini terletak pada pelaksanaan pekerjaan secara efisien, konsistensi terhadap aturan dan pembagian kerja, dan kemudahan dalam pengelolaan pegawai. Sementara sisi negatifnya adalah kecenderungannya untuk berubah menjadi kepemimpina tradisional (feudal) karena kekuasaan hierarkis yang diperolehnya (Boje \& Dennehy, 2006) Perilakunya pun seperti seorang raja: menuntut loyalitas pegawai, membangun nepotisme, dan berbau politik.

Di negara-negara yang memiliki karakteristik patron-client yang kental, sebagaimana diindikasikan oleh Soebhan (2000), fenomena disfungsi perilaku kepemimpinan semacam itu banyak ditemukan. Di Indonesia, kecenderungan kepemimpinan feodalistik di lingkungan birokrasi tumbuh subur pada era 32 tahun kepemimpinan Soeharto, dan sayangnya hingga kini budaya ini masih belum bisa dihilangkan. Meskipun reformasi sudah digulirkan pada 1998, dan berbagai kebijakan anti korupsi sudah diundangkan (melalui UU Nomor 31 Tahun 1999, UU No. 20/2001 dan UU 30 Tahun 2002, Inpres No. 5/2004, Kepres Nomor 11/2005) yang dibarengi pembentukan beragam lembaganya (Komisi Pemberantasan Korupsi, Tim Pemberantasan Korupsi, Tim Pemburu Koruptor), namun kolusi dan nepotisme yang berujung pada tindak korupsi di lingkungan birokrasi masih merajalela.

Demikian juga yang terjadi pada pelayanan publik. Meskipun beragam kebijakan telah diterbitkan (dari. Inpres No. 5 Tahun 1984, SK Menpan No. 81 Tahun 1993, Inpres No. 1 
Tahun 1995, Surat Edaran Menko Wasbangpan No. 56 Tahun 1998, hingga SK Menpan N0. 63 Tahun 2003), nepotisme dalam pelayanan yang didasarkan pada hubungan pertemanan, afiliasi politik, etnis, bahkan agama, masih saja berlangsung, yang berdampak pada semakin suburnya budaya suap dan pungutan-liar (LAN, 2003).

Apalagi kalau disadari betapa semakin besarnya tanggung-jawab birokrasi dalam menanggulangi krisis multi-dimensi yang semakin kompleks, maka model perilaku feodalistik kepemimpinan birokrasi tampaknya harus segera diakhiri. Sudah saatnya bagi para pemimpin birokrasi untuk bahu membahu dengan karyawannya dalam mengatasi berbagai permasalahan yang menghambat pencapaian visi dan misi organisasi. Dan ini berarti, mereka harus merubah pola kepemimpinan tradisional dengan model kepemimpinan transaksional.

\section{Kepemimpinan Transformasional}

Konsep kepemimpinan transformasional pertamakali dikemukakan oleh James McGregor Burns pada tahun 1978, dan selanjutnya dikembangkan oleh Bernard Bass dan para behaviourists lainnya. Bass (1085) mendefinisikan kepemimpinan transformasional sebagai 'kemampuan yang dimiliki seorang pemimpin untuk mempengaruhi anak buahnya, sehingga mereka akan percaya, meneladani, dan menghormatinya.'

Kompetensi transformasi seorang pemimpin mungkin dapat diukur dari kemampuanya dalam membangun sinergi dari seluruh pegawai melalui pengaruh dan kewenangannya sehingga lebih berhasil dalam mencapai visi dan misi organisasinya. Proses perubahan yang dilakukan pemimpin transformasional, menurut Bass, dapat dilakukan dengan cara: (1) meningkatkan kesadaran pegawai terhadap nilai dan pentingnya tugas dan pekerjaan; (2) mengarahkan mereka untuk fokus pada tujuan kelompok dan organisasi, bukan pada kepentingan pribadi; dan (3) mengembangkan potensi mereka seoptimal mungkin.

Implementasi kepemimpinan transformasional ini bukan hanya tepat dilakukan di lingkungan birokrasi, tetapi juga di berbagai organisasi yang memiliki banyak tenaga potensial dan berpendidikan. Secara organisasional, Leithwood dan Jantzi (1990) menulis bahwa penerapan model kepemimpinan ini sangat bermanfaat untuk: (1) membangun budaya kerjasama dan profesionalitas di antara para pegawai, (2) memotivasi pimpinan untuk mengembangkan diri, dan (3) membantu pimpinan memecahkan masalah secara efektif.

Budaya kerjasama dan profesionalitas dapat dibangun karena pemimpin transformasional akan memfasilitasi pegawainya untuk berdialog, berdiskusi, dan merencanakan pekerjaan bersama. Kerjasama yang terbentuk dari kegiatan ini akan memudahkan mereka untuk saling mengingatkan dalam melaksanakan tugas dan pekerjaan. Kebersamaan juga dilakukan dalam merumuskan visi dan misi organisasi, sehingga komitmen lebih mudah dibangun. Seorang pemimpin transformasional juga akan membagi kewenangannya melalui pemberdayaan pegawai, secara aktif mengkomunikasikan nromanorma dan nilai-nilai organisasi. Untuk mendukung perubahan budaya, Bass menyarankan untuk memanfaatkan mekanisme birokrasi yang selama ini telah dijalankan. 
Di samping itu, budaya yang dikembangkan tersebut, secara tidak langsung, juga akan memotivasi pemimpin untuk lebih mengembangkan diri. Dengan melibatkan staf dalam penyelesaian masalah-masalah strategis, pemimpin transformasional harus mampu meyakinkan mereka bahwa tujuannya jelas, rasional dan visioner. Berbagai kelebihan yang dimiliki atasan akan membantu para staf untuk bekerja secara lebih cerdas, bukan lebih keras. Di samping itu, keterlibatan staf dalam pemecahan permasalahan strategis juga akan meningkatkan pemahan bersama, bahwa permasalahan organisasi yang dipecahkan secara bersama akan lebih berhasil dibanding bila dipecahkan sendiri oleh pimpinan.

Berdasarkan diskusi di atas dan berbagai referensi, di bawah ini terangkum sepuluh prinsip kepemimpinan transformasi dalam lingkup birokrasi pemerintahan sebagai berikut:

1. Kejelasan visi: Kepemimpinan yang baik selalu mulai dengan visi yang merefleksikan tujuan bersama, dan dijelaskan kepada seluruh pegawai dengan gamblang dan sederhana.

2. Kesadaran pegawai: Selalu berusaha untuk meningkatkan kesadaran pegawai terhadap nilai dan pentingnya tugas dan pekerjaan mereka bagi organisasi.

3. Pencapaian visi: Berorientasi pada pencapaian visi dengan cara menjaga dan memelihara komitmen yang telah dibangun bersama.

4. Pelopor perubahan: Berani melakukan dan merespon perubahan apabila diperlukan, dan menjelaskan kepada seluruh pegawai tentang manfaat perubahan yang dilakukan.

5. Pengembangan diri: Mengembangkan diri secara terus-menerus melalui berbagai media pembelajaran untuk meningkatkan kompetensi kepemimpinannya.

6. Pembelajaran pegawai: Memfasilitasi kebutuhan pembelajaran pegawai secara efektif, dan mengembangkan potensi mereka seoptimal mungkin.

7. Pemberdayaan pegawai: Membagi kewenangan dengan cara memberdayakan pegawai berdasarkan trust, dengan mempertimbangkan kemampuan dan kemauan mereka.

8. Pengembangan kreativitas: Membimbing dan mengembangkan kreativitas pegawai dan membantu mereka dalam memecahkan masalah-masalah strategis secara efektif.

9. Budaya kerjasama: Membangun budaya kerjasama pegawai, dan mengarahkan mereka untuk mendahulukan tujuan kelompok dan organisasi daripada kepentingan pribadi.

10. Kondusifitas organisasi: Menciptakan organisasi yang kondusif dengan mengembangkan budaya kemitraan, komunikasi multi-levels, dan mengutamakan etika dan moralitas.

Dengan demikian, jelaslah bahwa kepemimpinan transformasional dapat memberikan berbagai pengaruh positif terhadap pegawai, pemimpin, dan organisasi. Dalam era globalisasi seperti sekarang ini, yang membutuhkan kerjasama dari seluruh komponen organisasi untuk memecahkan berbagai masalah strategis, model kepemimpinan semacam itu tampaknya tepat untuk diterapkan dalam lingkungan birokrasi. Budaya kerjasama yang terbentuk dapat merubah sikap mereka terhadap perkembangan organisasi dan peningkatan kinerja, dan perhatian yang ditunjukkan oleh pimpinan juga akan menciptakan iklim yang kondusif dalam organisasi. Pada akhirnya, seperti diasumsikan Erik Rees (2006), model kepemimpinan ini akan bermuara pada peningkatan kondisi ekonomi, sosial, budaya kerja, dan spiritual seluruh komponen organisasi.

\section{Menuju Transformasi Kepemimpinan Birokrasi}

Setelah mendiskusikan perbedaan antara dua model kepemimpinan dalam birokrasi, mungkin timbul pertanyaan, dapatkah kepemimpinan transaksional berubah menjadi 
transformasional. Untuk menjawab pertanyaan ini, pertama-tama perlu disampaikan bahwa dalam teori kepemimpinan terdapat tiga konsep dasar yang dapat mengubah seseorang menjadi pemimpin (Bass, 1989 \& 1990), yaitu (1) berdasarkan perilaku yang dimiliki (the trait theory), (2) berdasarkan suatu peristiwa penting yang terjadi secara tidak sengaja (the great events theory), dan (3) berdasarkan kemauan yang kuat untuk menjadi pemimpin.

Dengan demikian, kemauan keras merupakan kunci utama untuk dapat merubah perilaku kepemimpinan. Namun, tambah Bass, untuk mencapai tujuan perubahan seorang pimpinan harus mau mengembangkan diri melalui studi-mandiri, pendidikan, pelatihan, dan pengalaman sehari-hari secara terus-menerus. Bahkan, seandainya ia sudah dianggap berhasil.

Berdasarkan hasil diskusi tentang kepemimpinan transaksional dan transformasional di atas, dan untuk memudahkan proses transformasi, berikut ini disajikan perubahan arah dalam transformasi kepemimpinan yang dapat dilakukan di lingkungan birokrasi.

Tabel 7

\section{Perubahan Arah Transformasi Kepemimpinan Birokrasi}

\begin{tabular}{|c|c|c|}
\hline Kepemimpinan Transaksional & \multirow{3}{*}{$\begin{array}{l}\rightarrow \\
\rightarrow\end{array}$} & Kepemimpinan Transformasional \\
\hline Berdasarkan pada transaksi & & Berdasarkan pada visi \\
\hline $\begin{array}{l}\text { Menetapkan pedoman dan aturan tentang } \\
\text { pelaksanaan tugas dan pekerjaan }\end{array}$ & & $\begin{array}{l}\text { Meningkatkan kesadaran pegawai terhadap } \\
\text { nilai dan pentingnya tugas dan pekerjaan }\end{array}$ \\
\hline Berorientasi pada pengawasan & \multirow{2}{*}{$\begin{array}{l}\rightarrow \\
\rightarrow\end{array}$} & Berorientasi pada pencapaian visi \\
\hline Menolak perubahan & & Melakukan perubahan \\
\hline Berorientasi pada jabatan dan kekuasaan & \multirow{3}{*}{$\begin{array}{l}\rightarrow \\
\rightarrow \\
\rightarrow\end{array}$} & Mengembangkan diri secara terus-menerus \\
\hline Pegawai fokus pada tugas dan pekerjaan & & Memfasilitasi kebutuhan pembelajaran pegawai \\
\hline Kewenangan mutlak pada atasan & & Membagi kewenangan dengan pegawai \\
\hline Mengatur pelaksanaan pekerjaan & \multirow{3}{*}{$\begin{array}{l}\rightarrow \\
\rightarrow \\
\rightarrow\end{array}$} & Mengembangkan kreativitas pegawai \\
\hline Mengutamakan individualitas kerja & & Membangun budaya kerjasama \\
\hline Mengembangkan disharmoni organisasi & & Menciptakan organisasi yang kondusif \\
\hline
\end{tabular}

Selanjutnya perlu disepakati, bahwa tujuan transformasi kepemimpinan birokrasi adalah meningkatkan kompetensi kepemimpinan menjadi lebih baik. Kita tahu, konsep dasar kepemimpinan yang baik adalah karakter teladan dan pengabdian total kepada organisasi. Dalam pandangan pegawai, kepemimpinan adalah semua yang dilakukan atasan untuk mencapai tujuan dan menjaga keutuhan organisasi. Pemimpin yang dihormati dilihat dari siapa (sikap dan perilaku), apa yang diketahui (pekerjaan, tugas-tugas), dan apa yang dikerjakan (pelaksanaan tugas, cara memotivasi, dan memberikan arahan). 


\section{Penutup}

Setelah melakukan gebrakan dalam pemberantasan korupsi, fokus perhatian pemerintah tampaknya perlu dialihkan pada reformasi birokrasi pemerintahan. Agar lebih berhasil, reformasi seyogyanya dilakukan berdasarkan suatu grand strategy yang mencakup seluruh sistem kelembagaan organisasi pemerintah. Dalam kaitan inilah tampaknya pemerintah perlu membentuk sebuah komisi reformasi perbaikan birokrasi, yang tugas utamanya merumuskan payung kebijakan reformasi tersebut.

Perumusan grand strategy reformasi dapat dilakukan dalam beberapa tahap. Tahap awal adalah melakukan analisis permasalahan yang ada di dalam tubuh birokrasi. Di samping itu, perlu juga melakukan kompilasi berbagai konsep tentang pembaharuan birokrasi, yang dikemukakan oleh para ahli melalui beragam media.Tahap penting dalam strategi tersebut adalah internalisasi dan sosialisasi dari rumusan yang telah disusun untuk melihat reaksi dari dalam dan luar lingkungan birokrasi, sebelum diterbitkan secara resmi.

Melakukan reformasi birokrasi dengan pendekatan sistemik berarti mencakup seluruh sub-sub sistem yang ada. Di antaranya yang cukup signifikan adalah perilaku kepemimpina birokrasi. Kita tahu, karena pengaruh hierarki kekuasaan, implementasi kepemimpinan birokrasi banyak yang sudah bergeser dari model transaksional ke arah tradisional (feudal). Perilaku semacam inilah yang menuntut loyalitas total dari staf, mengembangkan nepotisme yang berujung korupsi, dan kental berbau politik kekuasaan.

Untuk mengubah malpraktik perilaku kepemimpinan birokrasi perlu dilakukan transformasi perilaku pemimpin. Perubahan ini hanya berhasil apabila ada kemauan keras dari pelaku kepemimpinan, dibarengi dengan usaha mengembangkan diri tanpa henti melalui studi mandiri dan berbagai media pembelajaran. Bahkan, dikatakan oleh Bass (1990), terus berlanjut walaupun seorang pemimpin telah dianggap berhasil meningkatkan kompetensi kepemimpinannya. Artinya, ia telah berhasil mengubah karakter dan kemampuan kepemimpinannya dalam melaksanakan tugas dan mempengaruhi pegawai, sehingga menjadi teladan bagi lingkungannya, dan pada akhirnya merubah kondisi ekonomi, sosial, budaya kerja, dan spiritual seluruh komponen organisasinya.

\section{Referensi}

Anwaruddin, Awang (2005), "Improving Public Service Delivery through Bureaucracy Reform", dalam ADB-NPASIPAG Conference Papers, Manila, The Phillipines: Asian Development Bank.

Bass, B. M. (1985). Leadership and performance beyond expectation. New York: Free Press

Bass, Bernard M. (1990). Handbook of Leadership, New York: Free Press.

Bass, B. M. (1990). From transactional to transformational leadership: Learning to share the vision. Organizational Dynamics, (Winter).

Betham, David (1974). Max Weber and the Theory of Modern Politics. London: Oxford University Press.

Bennis, Warren (1997). The Leadership of 21st Century dalam Ken Shelton (1997). A New Paradigm of Leadership. San Fransisco, Cal.: Executive Excellence Publishing.

Boje \& Dennehy Managing in Postmodern World - Chapter on Follett, Fayol, Weber, and Taylor. http://cbae.nmsu.edu/ dboje/mpw.html, 08/03/2006 
Caiden, Gerald E. (1976). Implementation - The Achilles Heel of Admninistrative Reform dalam Arne F. Leemans (ed.): The Management of Change in Government. The Hague, Netherlands: Martinus Nijhoff, 1976.

Davis, Keith (1967). Human Relations at Work. New York: McGraw-Hill, 1967.

Effendi, Taufiq (2005). Pembahasan tentang UU Pelayanan Publik antara Komisi II DPR dan Menpan dalam SK Suara Pembaruan, Jakarta: 12 Desember 2005

Fiedler, Fred E. (1969). Theory of Leadership Effectiveness. New York: McGraw-Hill.

Gintings, Sutradara (2005) dalam Saatnya Birokrasi Direformasi, Jakarta: Kompas Online, $10 / 12 / 2005$.

Gifford and Pinchot, Elizabeth (1993). The End of Bureaucracy and The Rise of The Intelligent Organization. San Fransisco: Barret-Koehler Publishers.

Homrig, Colonel Mark A, Transformational Leadership, http://leadership.au.af.mil/documents/homrig. htm, 2/18/20

Kilcullen, R.J. (1966) Max Weber: On Bureacracry. New York: Macquire University.

Kilgaard, Robert (1996). Introductory Remarks on Combatting Corruptio., The International Conference on Governance Institutions, Manila, The Phillipines, October 20-23, 1996.

Kwik Kian Gie (2003). Reformasi Birokrasi Dalam Mengefektifkan Kinerja Pegawai Pemerintahan. Jakarta: Bappenas.

Leithwood, Kenneth, and Doris Jantzi (1990). Transformational Leadership: How Principals Can Help School Cultures. Paper presented at annual meeting of the Canadian Association for Curriculum Studies (Victoria, British Columbia, June 1990)

Leithwood, Kenneth A (1992). The Move Toward Transformational Leadership. Educational Leadership 49, 5 (February 1992).

LAN (2003). Penyusunan Standar Pelayanan Publik. Jakarta: Lembaga Administrasi Negara. Muhammad, Mar'ie (2005) dalam PR Mendesak Bidang Ekonomi, Harian Bisnis Indonesia, Jakarta, 10/12/2005.

Mustopadidjaja AR (2002), Bureaucracy and Development of Reform dalam Mersmann dalam Gerhard and Gero von Harder. Change Management. Jakarta: Lembaga Administrasi Negara.

Osborne, David and Peter Plastrik (1997). Banishing Bureaucracy, Reading, MA: AddisonWesley Publishing Company.

Osborn, David and Ted Gaebler (1992). Reinventing Government. Reading, MA: A Plume Book.

Rasad, Fauziah (2006). Reformasi Birokrasi dalam Perspektif Pemberantasan Korupsi. Jakarta: Masyarakat Transpartansi Indonesia, http://www.transparansi.or.id, Januari 2006.

Rees, Erik, Seven Principles of Transformational Leadership, http://www.pastors.com/articles 8/10/2007

Soebhan, Syafuan Rozi (2000), Model Reformasi Indonesia, syafuan@indonet.com, 17/02/2006.

Soebhan, Syafuan Rozi (2005) dalam Saatnya Birokrasi Direformasi. Jakarta: Kompas Online, 10/12/2005. 
Sugiyarto, Guntur dalam SK Harian Kompas, Jakarta, 16/10/2005

Sianturi, Lobu Tolong (1984). Manajemen Kepegawaian. Jakarta: BPK Gunung Mulia.

Starch, Daniel (1943). How to Develop Young Executive Ability. New York: Harper \& Brothers Publisher.

Stogdill, Ralph M. (1974). Handbook of Leadership: A Survey of Theory and Research. New York: The Free Press.

Terry, George R. (1974). Principles of Management. New York: John Wiley \& Son.

Thoha, Miftah (2005). Urgensi Reformasi Birokrasi Pemerintah, Jakarta: Republika Online, $10 / 12 / 2005$.

Utomo, Tri Widodo W., et.al. (2005), Quo Vadis Reformasi Birokrasi: Sebuah Refleksi Perjalanan 7 Tahun Birokrasi Indonesia, Samarinda, PKP2A III.

Weber, Max (1947) , Max Weber: The Theory of Social and Economic Organization, translated by A. M. Henderson \& Talcott Parsons, New York: The Free Press.

Weber, Max (1987). Bureaucracy dalam Jay M. Shafritz dan Albert C. Hyde: Classics of Public Administration. Pasific Grove, California: Brooks/Cole Publishing Company, 1987.

Werther, William B. and Keith Davis (1996). Human Resources and Personnel Management (International Edition-Fifth ed.). USA: Irwin/McGraw-Hill.

Zuhro, Siti (2005) dalam Saatnya Birokrasi Direformasi, Jakarta: Kompas Online, $10 / 12 / 2005$. 